\title{
Immunisation of Labeo rohita with antigenic preparation of Aphanomyces invadans
}

\author{
M. K. YADAV, P. K. PRADHAN, N. SOOD, D. K. CHAUDHARY, D. K. VERMA, \\ U. K. CHAUHAN*, P. PUNIA AND J. K. JENA \\ ICAR-National Bureau of Fish Genetic Resources, Canal Ring Road, P.O. Dilkusha, Lucknow - 226002 \\ Uttar Pradesh, India \\ "Awadesh Pratap Singh University, Rewa, Madhya Pradesh, India \\ e-mail: pradhanpk1@gmail.com
}

\begin{abstract}
Aphanomyces invadans is an important fungal pathogen infecting freshwater and brackishwater fishes. In the present study, an attempt has been made to determine the effect of immunisation in Labeo rohita advanced fingerlings against $A$. invadans infection. The efficacy of the immunisation was evaluated by challenge with $A$. invadans as well as quantification of antibody level by ELISA. Following an initial immunisation in conjunction with adjuvant, the fish were given a booster dose after 35 days. After 14 and 28 days of the booster injection, blood was collected from the immunised rohu for monitoring the antibody level. The fish were also challenged with $A$. invadans zoospores to determine the relative percent survival. The immunised fish had significantly higher antibody level after 14 days of booster injection as compared to the control fish. However, the antibody level after 28 days of booster injection was not significantly different from the control fish. More importantly, similar to control fish, 100\% mortality was observed in the immunised fish challenged after 14 and 28 days of booster immunisation. Therefore, it can be concluded that it may not be suitable to induce protective immunity following immunisation with conventional antigenic preparations.
\end{abstract}

Keywords: Aphanomyces invadans, Immunisation, Labeo rohita

Infection with Aphanomyces invadans is a serious disease of freshwater and brackishwater fishes (Andrew et al., 2008; Oidtmann et al., 2008; Saylor et al., 2010; Oidtmann, 2012). More than 130 fish species are reported to be naturally affected by this disease (Boys et al., 2012; OIE, 2013; Kamilya and Baruah, 2014, Pradhan et al., 2014) and the host range is increasing (Boys et al., 2012, Songe et al., 2012). In India, the disease was first reported in 1988 and even after more than two decades of its first occurrence, outbreaks resulting in large scale fish mortalities have been reported (Pradhan et al., 2014). Till date, no effective treatment is available for this disease (OIE, 2013) and vaccination could be one of the health management strategies to counteract the disease. Although $A$. invadans invasion has been reported to elicit an antibody response, it is not clear whether the antibodies are protective (Thompson et al., 1997, 1999). Recently, Saikia and Kamilya (2012), following single immunisation in Catla catla with different antigens of $A$. invadans, reported that amongst the antigen preparations, fungal extract mixed with Freund's incomplete adjuvant showed the highest antibody production. However, these antibodies did not offer significant protection against A. invadans challenge. The authors suggested that one of the reasons for not showing protection could be that booster immunisation was not given. In the present study, an attempt was made to evaluate if vaccination could induce protective immunity against $A$. invadans infection, following a booster immunisation.

For the experiment, one hundred and fifty rohu (Labeo rohita) advanced fingerlings $(54.63 \pm 1.79 \mathrm{~g})$ were divided into five groups and stocked in fibre-reinforced plastic (FRP) tanks (@30 fish per tank) containing 10001 water in each tank. Approximately 30\% water was exchanged daily in the tanks. The fish were fed with a pellet diet @ 2\% of their body weight per day and acclimatised for 7 days in the tanks prior to immunisation. Water quality parameters such as temperature, $\mathrm{pH}$, dissolved oxygen, ammonia and nitrite were monitored in the experimental tanks and the mean values recored during the study period were $16.0 \pm 2.1^{\circ} \mathrm{C}, 7.9 \pm 0.43$, $5.45 \pm 0.68,0.107 \pm .026$ and $0.014 \pm 0.009 \mathrm{mg} \mathrm{l}^{-1}$ respectively.

A. invadans strain INM20101, used for zoospore production, in the present study was isolated from Cirrhinus mrigala during a recent EUS outbreak (Pradhan et al., 2014). Zoospores were prepared as described by Yadav et al. (2014). Briefly, four to five agar plugs (approx. $4 \mathrm{~mm}$ dia) of mycelium were put in a petri dish containing glucose peptone yeast (GPY) broth and cultured for 4 days at $20^{\circ} \mathrm{C}$. Thereafter, the agar was washed out by transferring through petri dishes with autoclaved pond water (APW) and fungal mats were left overnight at $20^{\circ} \mathrm{C}$ in APW. After about approx. $12 \mathrm{~h}$ of incubation, the secondary zoospores were 
harvested by centrifugation at $1000 \mathrm{~g}$ at $20^{\circ} \mathrm{C}$. Fungal extract was prepared as described by Lilley et al. (1997), briefly, the zoospore suspensions were added to an equal volume of $2 \mathrm{X}$ GPY broth. The germlings were grown for 3 days at $20^{\circ} \mathrm{C}$. Culture medium was decanted and the germlings were washed in $500 \mathrm{ml}$ sterile distilled water. Thereafter, germlings were harvested on sterile filter paper (Whatman 541) and excess water was removed. The fungal mats were ground in a pestle and mortar using liquid nitrogen. The resulting powder was homogenised in $1 \mathrm{ml}$ Wood's extraction buffer containing $1 \mathrm{~mm} \mathrm{MgC1}, 85 \mathrm{~mm}$ Tris $\mathrm{HC} 1$, $10 \mathrm{~mm} \mathrm{KC1,} 1 \mathrm{~mm}$ EDTA, $0.198 \mathrm{~g} \mathrm{l}^{-1}$ ascorbic acid and $1 \mathrm{~g}^{-1}$ glycerol at $\mathrm{pH} 7.5$ (Wood, 1988), with the addition of $5 \mu \mathrm{M}$ phenylmethylsulphonyl fluoride (Sigma-Aldrich, USA). Afterwards, the homogenate was centrifuged twice at $13000 \mathrm{~g}$ for $5 \mathrm{~min}$ and the concentration of protein in the extract was estimated as described by Bradford (1976) using a commercial kit (Fermentas Life Sciences, Vilnius, Lithuania). The protein concentration was adjusted to $5 \mathrm{mg}$ $\mathrm{ml}^{-1}$ with phosphate buffered saline (PBS) and the fungal extract was frozen at $-80^{\circ} \mathrm{C}$ until further use.

For the immunisation trail, 90 fish from 3 FRP tanks were immunised individually with $200 \mu \mathrm{g}$ fungal extract (in $100 \mu \mathrm{l})$, emulsified with Freund's incomplete adjuvant (1:1) by intraperitoneal route. The fish of the remaining two FRP tanks were intraperitonealy injected with $0.1 \mathrm{ml}$ sterile PBS which served as control group. Similarly, a booster dose was given to the immunised group as well as control group, after 35 days of $1^{\text {st }}$ immunisation. On 14 and 28 days of the booster immunisation, 5 fish from each tank were randomly sampled, anesthetised with MS-222 (Sigma-Aldrich) and bled through caudal vein. Serum was separated from the collected blood samples after allowing to clot and by centrifuging the clotted blood at $5000 \mathrm{rpm}$ for $5 \mathrm{~min}$. The serum samples collected were stored in deep-freezer at $-20^{\circ} \mathrm{C}$ for measuring antibody titre. For evaluation of protective immunity, on 14 and 28 days of booster dose, 10 fish from each immunised and control tanks were transferred to different tanks and challenged with 100 zoospores per fish by intramuscular injection below the dorsal fin. After challenge, mortality pattern of fish in both the groups was monitored and the relative percent survival (RPS) was calculated using the formula: RPS \% $=[1-(\%$ test mortality $/ \%$ control mortality)] x 100 . The cause of mortality was further confirmed by histopathological analysis for presence of fungal hyphae.

For monitoring the antibody level, the reactivity of the collected sera of vaccinated and control group fish to the antigen (fungal extract) was assessed by indirect ELISA which was performed in a 96 well microtitre plate as described by Das et al. (2009) with a few modifications. Briefly, the wells of the ELISA plates were coated with $50 \mu 1$ of the antigen $\left(0.5 \mu \mathrm{g} \mathrm{ml}^{-1}\right)$, diluted in coating buffer (carbonate-bicarbonate buffer, $\mathrm{pH}$ 9.6), whereas in antigen control wells, only coating buffer was added. The plates were incubated overnight at $4{ }^{\circ} \mathrm{C}$ and subsequently, the wells were washed with washing buffer i.e. PBS containing $0.05 \%$ Tween-20 (PBS-T). Thereafter, $100 \mu \mathrm{l}$ of $5 \%$ skim milk powder was added to the wells and the plates were incubated for $12 \mathrm{~h}$ at $4^{\circ} \mathrm{C}$. The wells were again washed in PBS-T followed by addition of $50 \mu$ of serially two fold diluted sera (1:50-1:200) and the plates were incubated overnight at $4{ }^{\circ} \mathrm{C}$. After washing with PBS-T, $50 \mu$ l of diluted 1: 16000 anti-rohu IgM monoclonal antibody (Rathore et al., 2008) was added to each well and left for $12 \mathrm{~h}$ at $4^{\circ} \mathrm{C}$. After washing with PBS-T, $50 \mu \mathrm{l}$ of 1: 4000 anti-mouse HRP conjugate (Sigma-Aldrich) was added to each well and incubated overnight at $4^{\circ} \mathrm{C}$. The plates were then washed and $50 \mu \mathrm{l}$ of ortho-phenylenediamine containing hydrogen peroxide $\left(\mathrm{H}_{2} \mathrm{O}_{2}\right)$ was added as substrate solutions and incubated at room temperature for $5 \mathrm{~min}$ in dark. The reaction was terminated by adding $50 \mu 1.25 \mathrm{M} \mathrm{H}_{2} \mathrm{SO}_{4}$. The colour development was read at $492 \mathrm{~nm}$ using an ELISA reader (Tecan, Grodig, Austria).

All the experimental data were expressed as mean \pm SE. Before analysis, data were checked for normality using Shapiro-Wilk test. Thereafter, one way analysis of variance (ANOVA) followed by the comparison of means as per Tukey's test available with SPSS (17.0 version, USA) were carried out. Finally, the level of significance was expressed as p-value less or greater than 0.05 .

The antibody titre in both groups was assessed by indirect ELISA. Compared to the control group, the immunised group showed significantly $(\mathrm{p}<0.05)$ higher antibody level on $14^{\text {th }}$ day post-booster immunisation. However, at $28^{\text {th }}$ day post-booster immunisation, the antibody level in immunised group declined and was comparable with the control group (Fig. 1). Interestingly, sera of control group fish showed cross-reactivity with the oomycete antigen.

Hundred percent mortality was recorded in both the immunised and control group following challenge of the fish after 14 and 28 days of booster immunisation and no

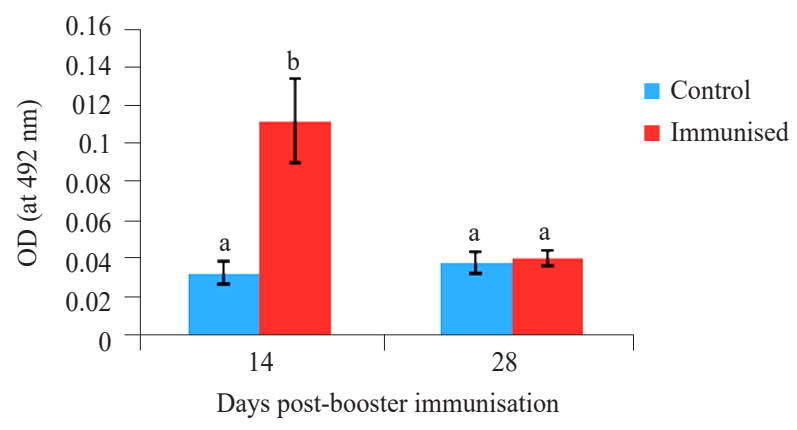

Fig. 1. Antibody levels of vaccinated and control L. rohita with $1 / 100$ serum dilution 
significant difference was observed in mortality pattern (p>0.05) (Figs. 2 and 3). In both the groups, gross lesions (slight swelling and redness) were observed at the injection site on 8 day post-injection (dpi) and by $12 \mathrm{dpi}$, clear swollen and reddish areas were developed in all the infected fish. Severely swollen haemorrhagic areas were observed on both sides of the body by $18 \mathrm{dpi}$. The mortality had started by the $20^{\text {th }}$ day after challenge and by $25^{\text {th }}$ day, there was $100 \%$ mortality in both the groups. Histopathological analysis indicated that in both groups, there was severe myonecrosis on both injected and non-injected sides and massive proliferation of hyphae was observed and there were no difference in the pathological features between control and immunised groups (Fig. 4).

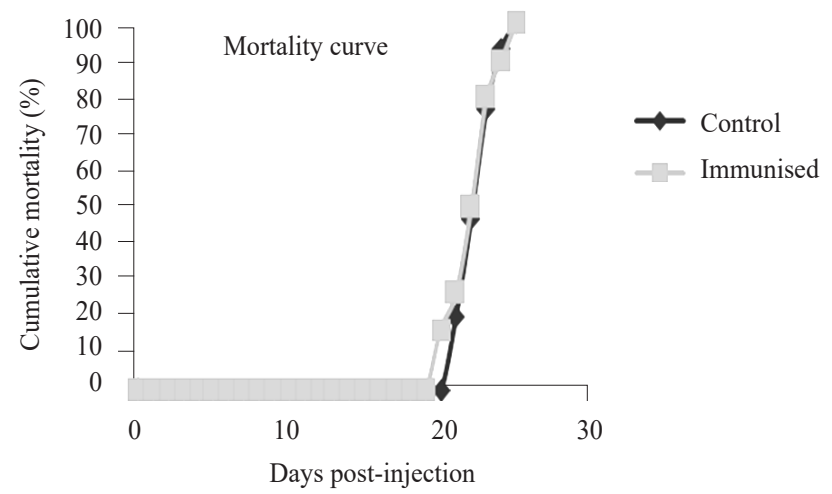

Fig. 2. Cumulative mortality of control and immunised groups of L. rohita challenged with Aphanomyces invadans on $14^{\text {th }}$ day of booster dose $(1: 1)$

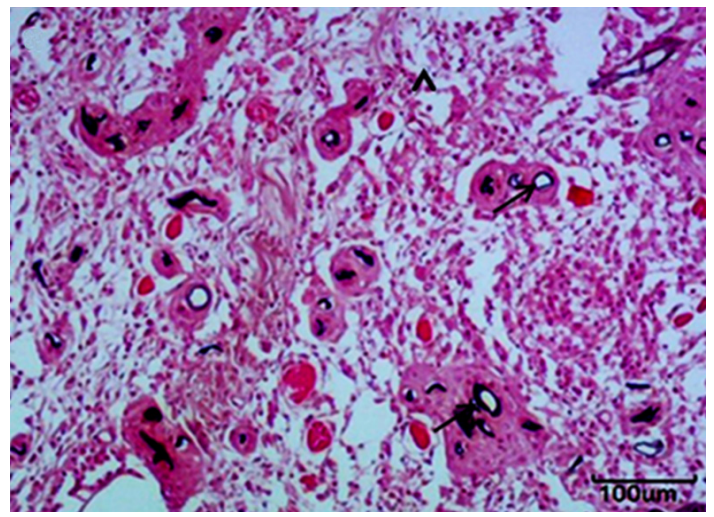

(a) et al. (2007) reported humoral antibody response against a pathogenic isolate of Saprolegnia parasitica following immunisation with antigenic extracts in brown trout Salmo trutta. Similarly, Saikia and Kamilya (2012) reported significant antibody response in Catla catla following single immunisation with fungal extract, fungal extract mixed with FIA and extracellular products. Previously, Thompson et al. (1999) also reported that immunised fish had significantly higher antibody level at $11^{\text {th }}$ week of immunisation,compared to the control group. In our study, the antibody level in the immunised group was comparable to control group on day 28 post-booster immunisation. The results indicated that increase in antibody level was transient. The crossreactivity of control sera as observed in the current study is

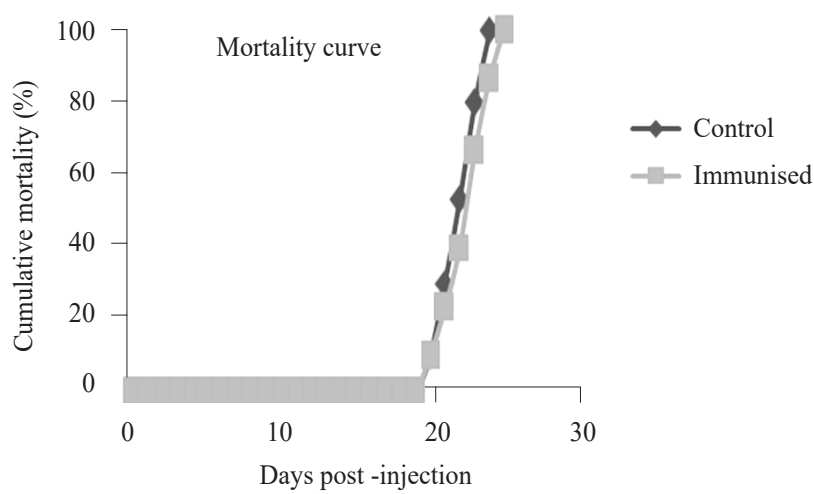

Fig. 3. Cumulative mortality of control and immunised group of L. rohita challenged with Aphanomyces invadans on $28^{\text {th }}$ day of booster dose

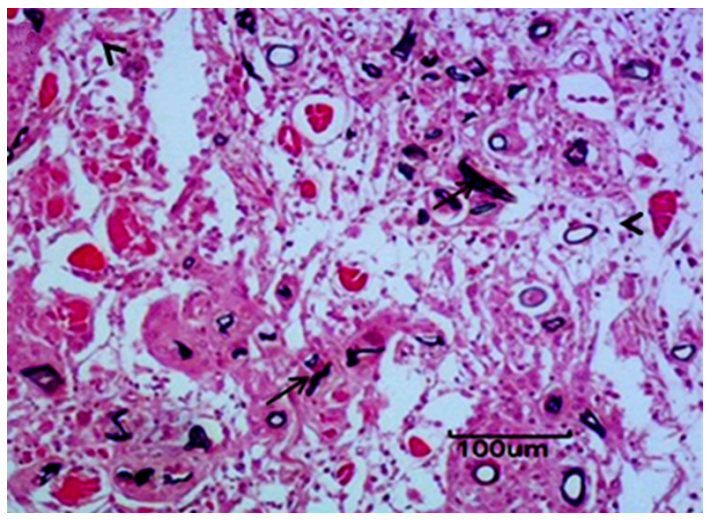

(b)

Fig. 4. Histopathology of control and immunised L. rohita challenged after booster immunisation with A. invadans at 24 dpi. a. control fish; b. Immunised fish. Lesion area showing extensive myonecrosis (arrowheads) and hyphae (arrows) (Grocott-Hand E)

As the immunised group of fish had significantly higher antibody level (detected by ELISA) compared to that of the control group at $14^{\text {th }}$ day post-booster immunisation, it was assumed that the antigenic preparation of $A$. invadans was able to induce humoral immune response in immunised fish. In accordance with our results, Fregeneda-Grandes in conformity with earlier report (Thompson et al., 1999) in which cross-reactivity of the control sera from rainbow trout with antigenic preparation of $A$. invadans was observed. The authors hypothesised that control fish could have been exposed to environmental fungi, which might have antigens common to $A$. invadans as well as an unspeciated Aphanomyces. 
The effectiveness of fish vaccinationin inducing protective immunity can be evaluated by experimental challenge with the homologous pathogen. In the present study, challenge of both the immunised and control group of fish with $A$. invadans indicated that there was no difference in the mortality pattern. Importantly, $100 \%$ mortality was observed in both groups of fish. In contrast to our findings, Saikia and Kamilya (2012) reported that there was reduction in the mortality percentage of the immunised group of fish, but it was not statistically significant $(p>0.05)$. The authors suggested that one of the reasons for not showing significantly higher protection against $A$. invadans in the immunised groups could be that secondary immunisation was not performed in their experiment. However, in the present study, fish were given a booster dose following primary immunisation and were challenged with less number of zoospores i.e. 100 zoospores per fish compared to 20000 zoospores by Saikia and Kamilya (2012). Therefore, it can be concluded that it may not be easy to induce protective immunity following immunisation with conventional antigenic preparations A. invadans. These findings of the present study may be helpful for further investigations on development of a protective vaccine against EUS.

\section{References}

Andrew, T. G., Huchzermeyer, K. D. A., Mbeha, B. C. and Nengu, S. M. 2008. Epizootic ulcerative syndrome affecting fish in the Zambezi River system in Southern Africa. Vet. Rec., 163: 629-632.

Boys, C. A., Rowland, S. J., Gabor, M., Gabor, L., Marsh, I. B. and Hum, S. 2012. Emergence of epizootic ulcerative syndrome in native fish of the Murray-Darling river system, Australia: hosts, distribution and possible vectors. PloS One, 7: e35568.

Bradford, M. M. 1976. Rapid and sensitive method for the quantitation of microgram quantities of protein utilising the principle of protein-dye binding. Anal. Biochem., 72: 248-254.

Das, P., Joardar, S. N., Abraham, T. J., Kamilya, D. and Batabyal, S. 2009. Dynamic changes in immune-effector characteristics of Indian major carp, rohu (Labeo rohita) sensitised with Aeromonus hydrophila. Indian J. Comp. Microbiol. Immunol. Infect. Dis., 30: 45-49.

Fregeneda-Grandes, J. M., Rodriguez-Cadenas, F., CarbajalGonzalez, M. T. and Aller-Gancedo, J. M. 2007. Antibody response of brown trout Salmo trutta injected with pathogenic Saprolegnia parasitica antigenic extracts. Dis. Aquat. Org., 74: $107-111$

Kamilya, D. and Baruah, A. 2014. Epizootic ulcerative syndrome (EUS) in fish: history and current status of understanding. Rev. Fish Biol. Fisher., 24: 369-380.
Lilley, J. H., Thompson, K. D. and Adams, A. 1997. Characterisation of Aphanomyces invadans by electrophoretic and Western blot analysis. Dis. Aquat. Org., 30: 187-197.

Oidtmann, B. 2012. Review of biological factors relevant to import risk assessments for epizootic ulcerative syndrome (Aphanomyces invadans). Transbound. Emerg. Dis., 59: 26-39.

Oidtmann, B., Steinbauer, P., Geiger, S. and Hoffmann, R. W. 2008. Experimental infection and detection of Aphanomyces invadans in European catfish, rainbow trout and European eel. Dis. Aquat. Org., 82: 195-207.

OIE 2013. Epizootic ulcerative syndrome In: Manual of diagnostic tests for aquatic animals. Office International des Epizooties p. 1-13, www.oie.int/fileadmin/Home/eng/Health_standards/ aahm/2010/2.3.02_EUS.pdf (Accessed 22 January 2014).

Pradhan, P. K., Rathore, G., Sood, N., Swaminathan, T. R., Yadav, M. K. and Verma, D. K. 2014. Emergence of epizootic ulcerative syndrome: large-scale mortalities of cultured and wild fish species in Uttar Pradesh, India. Curr. Sci., 106: 1711-1718.

Rathore, G., Kumar, G., Sood, N., Kapoor, D. and Lakra, W. S. 2008. Development of monoclonal antibodies to rohu (Labeo rohita) immunoglobulins for use in immunoassays. Fish Shellfish Immunol., 25: 761-774.

Saikia, D. and Kamilya, D. 2012. Immune responses and protection in catla (Catla catla) vaccinated against epizootic ulcerative syndrome. Fish Shellfish Immunol., 32: 353-359.

Saylor, R. K., Miller, D. L., Vandersea, M. W., Bevelhimer, M. S., Schofield, P. J. and Bennett, W. A. 2010. Epizootic ulcerative syndrome caused by Aphanomyces invadans in captive bullseye snakehead Channa marulius collected from South Florida, USA. Dis. Aquat. Org., 88: 169-175.

Songe, M. M., Hangombe, M. B., Phiri, H., Mwase, M., Choongo, K., Van-der Waal, B., Kanchanakhan, S., Reantaso, M. B. and Subasinghe, R. P. 2012. Field observations of fish species susceptible to epizootic ulcerative syndrome in the Zambezi River basin in Shesheke District of Zambia. Trop. Anim. Health Prod., 44: 179-183.

Thompson, K. D., Lilley, J. H. and Chinabut, S. 1997. The antibody response of snakehead fish, Channa striata (Bloch), to Aphanomyces invaderis. Fish Shellfish Immunol., 7(5): 349-354.

Thompson, K. D., Lilley J. H., Chen, S. C., Adams, A. and Richards, R. H. 1999. The immune response of rainbow trout (Oncorhynchus mykiss) against Aphanomyces invadans. Fish Shellfish Immunol., 9: 195-201.

Wood, S. E. 1988. The monitoring and identification of Saprolegnia parasitica and its infection of salmonid fish. $\mathrm{Ph} . \mathrm{D}$. Dissertation, University of Newcastle upon Tyne, UK.

Yadav, M. K., Pradhan, P. K., Sood, N., Chaudhary, D. K., Verma, D. K., Debnath, C., Sahoo, L., Chauhan, U. K., Punia, P. and Jena, J. K. 2014. Innate immune response of Indian major carp, Labeo rohita infected with oomycete pathogen Aphanomyces invadans. Fish Shellfish Immunol., 39: 524-531. 